\title{
A Case Study Study of agricultural market information system and their problems related to dissemination in Maharashtra state
}

- Urmila Bhushan Dhake and Pravinkumar Pandurang Kharade

See end of the paper for authors' affiliations

Correspondence to :

Urmila Bhushan Dhake

Agriculture Technical School, Manjrifarm, Pune (M.S.) India

Email : urmiladhake2010

@ gmail.com
Paper History :

Received : 29.07.2017:

Accepted : 27.02 .2018
ABSTRACT : Agricultural market information system collects, processes and disseminate information on the situation and dynamics of agricultural markets in order to improve public policies through increased awareness of market realities and to increase market transparency and by this way to lead to a fairer and more efficient allocation of recourses. Different institute in Maharashtra disseminating market information to large number of farmers. But there are some limiting factors and apparent constraint in agriculture information dissemination. Agriculture Market information system is essential not only for the formulation of a proper pricing policy and its successful implementation at a macrolevel, but also for farmers to aid them in improving their marketing performance. Accurate, adequate and timely information on all aspects of the crops traded is essential to operate efficiently.

KEY WoRds : Agricultural market information systems, MARKNET, Problems related to dissemination of market information

How To Cite This PAper : Dhake, Urmila Bhushan and Kharade, Pravinkumar Pandurang (2018). Study of agricultural market information system and their problems related to dissemination in Maharashtra state. Internat. Res. J. Agric. Eco. \& Stat., 9 (1) : 239-243, DOI : 10.15740/HAS/IRJAES/9.1/239-243. 